\title{
Beyond Humanitarian Logics: Volunte er-Refugee Encounters in Chios and Paris
}

\author{
Abstract \\ This paper focuses on self-organized, grassroots volunteers who have emerged as key actors in \\ the humanitarian response to Europe's contemporary "refugee crisis." Based on ethnographic \\ research on the Greek island of Chios and in Paris and taking established critiques of \\ humanitarianis $\mathrm{m}$ as our point of departure, we explore how volunteers providing humanitarian \\ care navigate the ethical and political dilemmas traditionally encountered by aid workers. More \\ specifically, we ask: what kinds of social relations do volunteers enact through their practices \\ and in their everyday encounters with refugees in and beyond refugee camps? How do the \\ specific qualities of these encounters affect the possibilities of enacting alternative modes of \\ humanitarian practice? Focusing firstly on volunteer-refugee interactions during camp \\ distributions - the paradigmatic mode of humanitarian work - we explore how volunteers \\ simultaneously mimic disciplinary humanitarian practices and engage in processes of ethical \\ deliberation that inform more dignified forms of care. Secondly, we show how everyday \\ volunteer-refugee interactions, formed within diverging spatiotemporal contexts of the two sites, \\ lend themselves to exchanges of "biographical life," opening up spaces for creative solidarities \\ with refugees and more political interventions vis-à-vis the contemporary border regime. We \\ conclude that commonly considered humanitarian logics of depoliticization and dehumanization \\ are not guaranteed outcomes of volunteer humanitarianism. Instead, some of the volunteer \\ practices and everyday encounters that we document hold the potential for more fluid and \\ humane responses to an ever-changing landscape of refugee flows and containment.
}

Keywords: Refuge es; volunteers; humanitarianis m; camps ; migration; Europe 


\section{Introduction}

In the autumn of 2017, authorities on the Greek island of Chios began the long-awaited process of dismantling Souda, a refugee camp in the main town that had been providing shelter to approximately 1,000 people at the time. Leaving the military-run EU "hotspot" Vial - a remote, abandoned factory surrounded by barbed wire - as the only "reception" site on the island, a longterm volunteer reflected on the implications:

... due to Souda being an open camp, volunteers have been able to identify and support the most vulnerable refugees, as the authorities and humanitarian organizations have failed time and time again ... Had they been locked away behind the fences of Vial, we would have known of their existence, but not who they are - neither of their history [n]or struggles. We would not have been able to listen, to stand in solidarity with them, or do them the justice of documenting their experiences. ${ }^{1}$

The above quote captures some of the defining features of the grassroots provision of care to people arriving at Europe's borders since the "long summer" of $2015 .^{2}$ It also raises several recurrent ethical and political dilemmas inherent to humanitarian action. How does one practice an ethics of care that goes beyond maintaining physical survival to fully recognize human dignity in spaces that are "dehumanizing by design," without becoming implicated in regimes of control? ${ }^{3}$ How does one effectively bear witness to injustice when faced with systematic rights violations and the violent abandonment by the state? These dilemmas are, of course, not unique to the work of volunteers; they mirror those experienced by professional aid workers within humanitarian NGOs. ${ }^{4}$ The question, however, arises in how far the distinct self-identified values, 
roles, structures, and politics that many grassroots volunteers subscribe to allow them to navigate these tensions and reimagine everyday encounters with refugees in ways that challenge humanitarian business-as-usual within Europe's so-called "refugee crisis."

Volunteers have historically played an important role in humanitarian NGOs such as Médecins Sans Frontières (MSF) or the International Committee of the Red Cross (ICRC). Yet, it is the unprecedented number of grassroots volunteers operating outside the purview of the institutionalized regime of humanitarian care that sets the humanitarian landscape in Europe apart and calls for further investigation. From the Greek islands, along the Balkan route, to the "Jungle" camp in Calais and informal settlements in other cities, self-organized networks of local and international volunteers have developed complex and versatile systems for the provision of aid to people on the move, filling the many gaps left by the state and established NGOs: from food, clothing, tents, and sleeping bags, to emergency housing, informal education, legal and medical aid.

This paper seeks to contribute to literature on the ethics and politics of humanitarian action and, in particular, the nascent debate about the distinct nature of what some have termed "volunteer" or "solidarity" humanitarianism. ${ }^{5}$ Based on ethnographic research in two sites marked by an intense presence of volunteers - the refugee camps on Chios and in Paris - we seek to capture the suppleness of volunteers' relationships and interventions, the emergent politics that are premised on everyday volunteer-refugee encounters, and the specific spaces that are opened up for and by alternative forms of humanitarian action. In doing so, we approach humanitarianism not as an "absolute value" but rather as "an array of embodied, situated practices emanating from the humanitarian desire to alleviate suffering of others." ${ }^{6}$ Situated amidst calls for "thinking the camp "from below," we treat camps as social, affective, and 
political spaces shaped by conflicting practices and discourses of governmental and nongovernmental actors, volunteers, activists, and refugees themselves. ${ }^{7}$ While recognizing the diversity in refugee camps across Europe, one of our aims is to draw to the fore the particular spatiotemporal contexts of the camps in Chios and Paris, and how these shape volunteer-refugee encounters.

Thus, in this paper, we ask: what kinds of actors converge in the camp as a humanitarian space and what kinds of refugee-volunteer encounters produce social relations that exceed humanitarian logics? What is the relationship between how volunteers understand themselves and the kinds of practices and relations they enact? How do the specific qualities of volunteerrefugee interactions and volunteer practices affect the possibilities of enacting alternative modes of humanitarian practice?

Our empirical analysis proceeds to critically examine three dimensions of volunteerrefugee encounters. We firstly focus on the micro-politics of volunteer-refugee relations in "the line" during distributions, the paradigmatic mode of humanitarian work in refugee camps. We explore how volunteers simultaneously mimic the "policing" practices of established humanitarian agencies and seek to challenge their dehumanizing effects, thereby shifting the parameters of humanitarianis $m$ in some ways but not in others. Secondly, we examine how everyday social interactions between volunteers and refugees may lead to exchanges of "biographical life" and contribute to processes of ethical deliberation. ${ }^{8}$ Such deliberations range from practical concerns of implementing more humane distribution systems to broader political dilemmas about volunteers' complicity with exclusionary migration regimes. It is the latter, and the politics, possibilities, and limits of volunteer-refugee solidarities that form the third part of our analysis. 
Two closely related claims emerge from our analysis. Firstly, we suggest that the everyday presence of volunteers has opened up a different type of encounter with refugees, where the twin humanitarian logics of depoliticization and dehumanization are not guaranteed outcomes. There are, we claim, certain specific qualities to volunteer-refugee interactions that foreground "biographical life" and resulting volunteer practices of témoignage that may offer alternatives to "established schemata of humanitarian action." Secondly, we argue that the volunteer-refugee solidarities formed in the spatiotemporal context of makeshift camps carry possibilities, however fleeting and precarious, for generating "new affective and political grammars in response to suffering, injustice and death" that reach beyond the confines of "humanitarian reason."10

\section{Humanitarian Logics: Between Compassion and Control}

In order to interrogate how volunteers in Paris and Chios navigate the contradictions of working alongside but also against the humanitarian apparatus tasked with managing the refugee response, we engage with three sets of closely intertwined debates. Firstly, we situate our discussion amidst the fundamental contradictions of humanitarianism, highlighting two central logics that underpin humanitarian action in refugee camps. This is followed by a review of existing critiques of humanitarian volunteering - its history, politics, and professionalization and emerging literature on volunteer-driven "forms of vernacular humanitarianism" across Europe. ${ }^{11}$ Thirdly, we examine how volunteer-refugee relations are shaped by the spatial and temporal configurations of camps that blur the lines between "formal" and "informal" in terms of design and management.

While humanitarianism as a concept encompasses a range of meanings and a contested genealogy far beyond the scope of this review, there is a broad consensus that a particular 
humanitarian imaginary has come to occupy "a key position in the contemporary moral order."12 The tens of thousands of volunteers from across Europe (and beyond) who have flocked to Greek islands such as Lesbos and Chios, camps in Northern France, and increasingly cities like Paris and Athens since 2015, demonstrate the power of this social imaginary. We draw here on Fassin's concept of "humanitarian reason," defined as the "principle under which moral sentiments enter the political sphere."13 These moral sentiments are expressed in various ways but are linked mainly to notions of hospitality, charity, compassion, and care-affective states that are nourished by the sense that we are personally connected and concerned with the plights of others. According to Fassin, humanitarian reason underpins the everyday workings of "humanitarian government," the vast globalized ensemble of infrastructures, practices and procedures of states, NGOs, and international agencies whose task is "to manage, regulate, and support the existence of human beings" categorized as weak, vulnerable, and precarious. Of course, these affective states and the practices they inform can have deeply problematic repercussions for "beneficiaries," as humanitarian action is structured by a fundamental "tension between inequality and solidarity, between a relation of domination and a relation of assistance...constitutive of all humanitarian government." 14 Compassion, for instance, is critiqued due to the inequality underpinning it, an emotion, ethic, and in public spaces, affect, that is hierarchical in its display. It may produce "discriminatory and even violent consequences," particularly when it displaces an approach rooted in rights and reinforces a hierarchy of lives. ${ }^{15}$ Inequality, then, constitutes the very condition of possibility for humanitarianism and, consequently, the humanitarian worker, including the volunteer, is seen as perpetually existing in an asymmetrical relationship to refugees. 
Ethnographic research has done much to expose this tension between "compassion and repression" in the context of refugee camp management. ${ }^{16}$ Malkki's much-cited work shows how "humanitarian compassion," driven by the fundamental impetus to save and sustain precarious lives, paradoxically, sets in motion a dehumanizing logic through its construction of the "ahistorical, universal humanitarian subject." In the humanitarian imaginary, refugees are effectively reduced to "speechless emissaries," victims denied the capacity to assert their voice in how their past and futures are represented. ${ }^{17}$ Humanitarian government thus reproduces a thoroughly dehistoricized and depoliticized figure of the refugee such that, in Arendt's words, only "the abstract nakedness of being human" remains. ${ }^{18}$ This line of critique echoes the extensive literature on the "biopolitical" management of refugee camps, which has done much to unmask the complicity of humanitarian care in regimes of control whereby "refugees are cared for in terms of their security and their biological needs, while...deprived of political agency." 19 Importantly, for Ticktin, the logic of depoliticization extends beyond the governance of humanitarian spaces to the very capacity of humanitarian reason to confront the violence of borders. Given its focus on individuals rather than structural realities, she argues, "compassion cannot by itself further a politics of equality." 20

In our own work, Brun's writing on humanitarian workers in Jordan's refugee camps is particularly useful to conceptualize the distinctive nature of volunteer-refugee interactions. Brun approaches humanitarianism through Fassin's differentiation between biological and biographical life, where "biographical life" relates to people's "ability to act within or upon the forces that shape and restrict [their] possibilities to reach a desired future." ${ }^{21}$ It is the basis on which refugees can give an account of their lives and "give a meaning to their own existence." 22 While Agier and Ticktin see the effects of depoliticization and dehumanization on and across 
bodies, structures, and spaces, Brun finds the redemption of humanitarianism through "biographical life", even if elusive in her own empirical research. ${ }^{23}$ Brun shows that humanitarian aid workers focused primarily on refugees' immediate material needs. Set firmly within a temporality of emergency, their activities oriented towards short-term relief and saving biological lives. The consequent erasure of refugees' pasts, subjectivities, identities - their biographical lives - and the foreclosure of their futures emerges as a necessary precondition for sustaining principles of neutrality and impartiality that ostensibly govern the conduct of humanitarian actors. "Human zoology exceeds biography," writes Redfield in his account of MSF work in refugee camps: "those whose dignity and citizenship is most in question find their crucial measurements taken in calories rather than in their ability to voice individual opinions or perform acts of civic virtue." 24

In sum, what emerges from many critical studies of humanitarianism are a set of closely intertwined humanitarian logics that permeate the darker side of humanitarian government. However, the way the underlying contradiction between solidarity and inequality plays out, we argue, becomes muddled when looking at grassroots volunteers, who are distinct from professional humanitarian workers in terms of experience, pay, motivation, relative institutionalization, and self-identified roles. Thus, how far do the everyday practices and social relations that volunteers enact depart from those of professionalized humanitarian actors and allow for biographical life to emerge, thereby broadening the temporal limits of humanitarian action? And, more generally, how are we to understand humanitarian volunteering in the shifting architecture of refugee management across Europe?

\section{Volunteers as Humanitarian Actors}


Since the inception of the Red Cross movement in the mid-19th century, the figure of the volunteer has been intimately bound up with the humanitarian project, whose history "seeps into and intertwines with other histories, of charity, of voluntary action." 25 Our aim here is not to present a full history of the role of volunteers in the shifting practices, discourses, and accompanying social imaginaries of humanitarianis m, nor to settle on a single definition of the "volunteer." Rather, our aim is to draw out key parallels and points of distinction between voluntary-based humanitarian action and the work of professionalized NGOs and situate our discussion within the specific humanitarian landscape in Europe.

Numerous NGOs that have become prominent faces of humanitarian relief such as MSF, Red Cross and Oxfam began as largely volunteer-based efforts. For example, European volunteers, some of whom operated under the auspices of MSF, played an important role inside Cambodian border camps from 1979-1993, a period which overlapped with the growing institutionalization and professionalization of the humanitarian field. As Taithe explains, these humanitarian spaces became the laboratories for the production of knowledge and practices that have "since reached deep and far in the nascent international humanitarian networks." With many of those volunteers going on to work for leading NGOs, they eventually "impacted the shaping of what was later called the 'humanitarian system' as a whole."26

Elsewhere, Feldman recounts multiple ethical dilemmas encountered by volunteers working with the American Friends Service Committee (AFSC), a Quaker NGO, in Gaza in the late 1940s. While characterized as providing "silent help" by the Nobel Peace Prize committee, AFSC volunteers, as shown by Feldman, continuously grappled with "how to balance their ethics of interaction [with refugees] with their equally strong concern about the ethics of outcome." This dilemma took place on multiple levels: whether the balance could be struck in their mission, 
through the method of personal interactions, or through the self-awareness of volunteers themselves. In their everyday work, however, AFSC volunteers had to routinely depart from their Quaker values. They not only had to co-operate with military authorities but, most importantly, could not enact the close relations with refugees they had envisaged - an ethics of care that, similar to Brun, foregrounds biographical life. Instead, volunteers were often compelled to employ punitive methods - such as "withholding food to entire villages" when recipients were caught cheating the system. Thus, while AFSC volunteers recognized refugees as political actors in their own right ultimately their "humanitarian practice was driven by pressures of efficiency and concerns about management that produced justice and relief, and human rights and humanitarianis $\mathrm{m}$, as separate regimes of action."27

The attempt to overcome this divide was the impetus behind the foundation of MSF in 1971 which has cultivated witnessing as one of the central pillars of its humanitarian practice. Incorporated into MSF's official charter, témoignage is defined as "the presence of volunteers among populations in danger motivated by concern for the fate of fellow human beings... and the duty to report on the situation and on the fate of these people." 28 Rejecting the ICRC's restrictive conventions on speaking out, MSF's tradition of bearing witness has evolved into a "mechanism for translating moral claims into political action." 29 Despite varied interpretations and internal disagreements on the extent to which becoming involved in political debates could detract from field activities - a reflection of the "enduring tension" between neutrality and advocacy - MSF routinely mobilizes its collective voice and professionalized media apparatus to denounce government policies. ${ }^{30}$ However, Redfield is clear that témoignage is "not quite a full politics." 31 Rather, it is an approach "to the defense of life that both recognizes and refuses politics", an "ethic of refusal" where political denunciation occurs but "final responsibility for alleviating suffering 
lies elsewhere." ${ }^{32}$ Nonetheless, as Givoni argues, practices of witnessing introduce an important corrective to accounts of humanitarian action that assert a clear-cut divide between the moral and the political as "a primordial and decisive feature of humanitarian reason," and one, we believe, that allows for a more nuanced theorization of grassroots volunteering in Europe. ${ }^{33}$

\section{Situating Volunte ering in Europe}

The accounts of the internal dilemmas faced by humanitarian actors over professional identity, ethical encounters with refugees, and the politics of witnessing inform how we approach the role of volunteers in France and Greece. Yet, as we document below, how exactly volunteer collectives navigate these dilemmas differs in subtle but significant ways. Moreover, there are also important differences between the NGO interventions that drew on the labor of volunteers recounted above and today's humanitarian volunteering landscape in Europe.

One difference is the sheer scale of the phenomenon: in one estimate, more than 50,000 volunteers spent time on the Greek island of Lesvos in one year alone. ${ }^{34}$ Secondly, the organizational structure differs markedly from cases where volunteers operate within institutionalized organizations such the ICRC or MSF, whose operations, facilitated by an army of professional logisticians, doctors, pharmacists, accountants, lawyers, policy experts, and other salaried staff, span the entire globe. Moreover, as in Malkki's research on Finnish Red Cross "humanitarians," volunteers within such NGOs are generally "paid professionals." 35 By contrast, in Northern France and on the Greek islands, the landscape has been dominated by grassroots, self-organized collectives that emerged in the context of "a relatively empty regulatory environment." While there were long-standing organizations with clear leadership structures that shifted into the volunteer space, many teams were set up as ad-hoc, small-scale operations with 
"minimalist decision-making hierarchies" and a shifting pool of volunteers, to respond to the sharp rise in refugee arrivals in $2015 .{ }^{36}$

The volunteers we met exist across a spectrum, from seasoned anarchists who espouse a borderless world to first-time volunteers who were motivated by seemingly apolitical, humanitarian concerns after watching the "crisis" unfold in the media. While there is no "typical" socio-economic profile of the volunteers - ranging from university students, teachers, social workers to corporate lawyers - many are white, young, and middle-class and differ from the populations they come to assist by European (and/or North American) citizenship status. ${ }^{37}$ Some volunteer for just a few days, others for several months, taking on various coordination roles. Some are locals and members of long-established refugee support groups, while many teams have an international composition. Crucially, they have by and large been founded, coordinated and staffed by individuals with no prior experience in humanitarian work. Yet, despite their "amateur" character, volunteers across Europe have been able to establish complex, versatile, transnationally linked networks for humanitarian assistance, which facilitate the crossborder circulation of volunteers, aid, and knowledge across different refugee nodes. These grassroots structures thus operate alongside and, as we shall see below, frequently in tense relations with established humanitarian and state actors.

While it is impossible to do justice to the multiplicity of organizations, motivations, experiences, and ideologies that make up the volunteering space in Europe, we build on Sandri's notion of "volunteer humanitarianism" to highlight the "improvisation, informality, geographical proximity, sociality, and activism" that distinguishes grassroots volunteers from professional humanitarian actors and that, we argue below, allows for distinct volunteer-refugee encounters to emerge. ${ }^{38}$ According to Feldman, the focus on everyday relations and interactions constitutes "an 
important analytic angle for investigating humanitarianism" as it allows us to chart how the inevitable compromises of humanitarian work play out in concrete settings. ${ }^{39}$ This, then, raises the question that is at the heart of our investigation: where exactly to situate the refugeevolunteer encounter in Europe's humanitarian landscape in terms of ethics and politics.

Several scholars have sought to grapple with this emergent form of volunteer-led "solidarity", “amateur", or "makeshift" humanitarianism. ${ }^{40}$ Writing about the Greek context, Rozakou argues that these "forms of vernacular humanitarianism" seek to "subvert the dominant hierarchical schemata of humanitarian action" by resisting bureaucratization; instead, grassroots actors foreground "social relationships with the refugees they met." 41 In Greece, the notion of volunteering emerged in the early 2000 s as a state-sponsored, top-down project to "modernize" Greek civil society through the "institutionalization and professionalization of volunteerism." 42 This project ran alongside and, indeed, counter to the more politicized solidarity networks based on principles of mutuality, informality, and horizontality that emerged in response to Greece's deep economic crisis and that subsequently played a central role in establishing makeshift systems for the reception of refugees arriving to the Greek islands as of 2015. In this context, the term "solidarian," initially confined to anarchist circles, became commonly used in opposition to Mikiades - "the professional NGO workers who also became key actors in the field." 43 It has been used to explicitly reject the label "volunteers," whom "solidarians" accuse of practicing a humanitarianis $m$ that reinforces relations of inequality, and that sits too close to the official humanitarian apparatus. What Rozakou terms "solidarity humanitarianism" emerged from this specific socio-cultural context - a concept that is particularly useful for our analysis as it brings to the fore situated and embodied attempts to practice a different kind of encounter with refugees and overcome the distinction between compassion and solidarity discussed earlier. 
Contrary to the culturally-specific manifestation of Greek "volunteerism," much of the literature on grassroots interventions in France focuses on voluntary organizations that are international in composition. Nonetheless, several studies have identified similar dynamics at play. For example, Sandri and Bugoni write about the "makeshift" humanitarianism that emerged in the Calais "Jungle" through the work of collectives that were able to establish an alternative to the "humanitarian machine," with aid provision occurring outside of institutionalized humanitarian structures. For example, the volunteer-run medical team Lotus "refused to register refugees [and] asserted that their role was not one of policing but instead protection of camp residents." While Lotus volunteers did not self-identify as activists in the same way as more overtly politicized groups operating in the camp, their presence nonetheless had a clear political dimension: "unlike MSF and other humanitarian NGOs, whose mandates do not incorporate the pursuit of justice or an improved social order, volunteers took it up on themselves to oppose the strict migration regime and the violence perpetrated against refugees." 44

The "progressive politicization" of volunteer collectives is a core theme that cuts across much of the emerging empirical literature on humanitarian volunteering in Europe ${ }^{45}$ In her reading of "volunteer humanitarianism," Sandri argues that new social spaces emerged through the presence of volunteers in Calais, which allowed for expressions of charity and political solidarity. Rooted in their "lived experiences" in the Jungle, she describes how volunteers began circulating petitions against the absence of state provision and agitating against the border regime. Thus, "grassroots organisations [that] were not initially motivated by political considerations ... but by humanitarian concerns" evolved into ones that became increasingly politicized. ${ }^{46}$ 
Some are more skeptical of the progressive potentialities of grassroots volunteers and highlight not only how the presence of volunteers may further regimes of control, as we document below, but how their humanitarian sensibilities, affects, and modes of engagement with refugees may further unequal relations. For example, in her account of volunteering on Lesvos and Chios, Knott suggests that while many international volunteers were driven by a humanitarian compulsion to "do something," they often engaged in social media showcasing of their work or, more problematically, ended up reinforcing Orientalist practices of othering through everyday interactions with refugees ${ }^{47}$ However, it is revealing that Knott's claims are largely based on participant observation of a Norwegian volunteer collective on Chios - A Drop in the Ocean - which, in terms of its hierarchical structure, degree of institutionalization, and branding, resembles a professionalized NGO. Freedman takes her critique of volunteers in Calais and Lesvos a step further: not only did "amateur" volunteers hinder the work of "professional" agencies but the relations they enacted reinforce "dominant representations of refugees as dehistoricised and depoliticised "victims." Moreover, "the political silence" of "volunteer humanitarians," she claims, helps governments evade responsibilities to protect refugees and renders them blind to their own complicity in Europe's "politics of repression." 48

Thus, similar ethical and political dilemmas mentioned earlier in the cases of MSF and AFSC emerge for grassroots volunteer organizations. The intention here is not to dichotomize established NGOs and grassroots collectives and, indeed, it is unclear whether the practices of volunteer collectives constitute a rupture from dominant humanitarian schemata, or rather differences in sensibility and form. An added difficulty in situating volunteer humanitarianism and its effects as either internal or external to the "humanitarian machine" also stems from the diverse political backgrounds that volunteers occupy and lack of homogeneity in how they self- 
identify. Thus, we seek to avoid a one-dimensional reading of volunteer humanitarianism as merely reinforcing relations of inequality or marking a singular break with established modes of humanitarianism, and add more empirical and analytical nuance to these debates by exploring everyday volunteer-refugee interactions in and beyond the camp.

\section{Spaces of volunte er humanitarianis m}

If both the refugee and the volunteer are central figures in contemporary humanitarianism, refugee camps are the "quintessential humanitarian spaces." 49 Our point of departure in interrogating volunteer humanitarianism is that refugee camps must be conceptualized as spaces "where sociality is (re-)created, social hierarchies are produced and politics continues to have significance." ${ }^{50}$ Amidst the generalized state of precarity - especially in makeshift settlements camps are also "lived" spaces where people continually exercise agency as they "negotiate, cooperate, fight, resist, and ultimately live." Most importantly for our purpose, they are spaces where "social solidarities" are formed between people who inhabit camps on one hand and activists and volunteers on the other - a "power of life", in Katz's words, albeit tentative and precarious..$^{51}$

Furthermore, as we researched various spaces, the need to dissolve arbitrary boundaries that demarcate refugee spatialities became apparent. As Katz shows, refugee camps "created topdown by state and municipalities" now frequently appear in close proximity to informal settlements, particularly in urban settings like Paris, "sometimes to the point where they intersect, penetrate, and transform each other into hybrid spatial entities." ${ }^{52}$ In contrast to the vast UNHCR-administered camps in sub-Saharan Africa described in the work of Agier for instance, these intersecting spatialities become intimately linked through the circulation of refugees, 
volunteers, humanitarian discourses and makeshift practices. ${ }^{53}$ For instance, volunteers move between warehouses, accompany refugees to hotels and hospitals, socialize in cafes and city plazas, and facilitate social activities within and outside the gates of camps. The dichotomy between "top-down/formal" versus "informal/makeshift" becomes further complicated for Katz when considering that autonomy can exist even in the former, particularly when migrants have the flexibility to adjust physical structures to resonate with their everyday lives, or are compelled to do so due to the lack of infrastructure. Finally, the typology of the "camp" can shift over time depending on changing migrant routes and the varying state and local authorities, private companies, NGOs, and volunteer groups that are involved in camp management. Thus, we aim to identify how refugee-volunteer encounters in particular spaces may foreground biographical life and engender more political modes of volunteering or, conversely, reproduce dominant humanitarian logics.

\section{Methods}

In response to the dilemma of conducting ethical research amidst vulnerable individuals, "volunteer-as-a-methodology" facilitates access to humanitarian spaces, while also providing the closest semblance to situated solidarity. ${ }^{54}$ Our fieldwork entailed repeat visits to Chios and Paris between March 2016 and July 2018, during which we conducted semi-structured interviews with volunteers and refugees and engaged in participatory observation by joining different volunteer groups. ${ }^{55}$ We took part in a variety of tasks: from patrolling the shores on Chios, attending to new arrivals, identifying and referring vulnerable persons, conducting needs assessments in the camp, to sorting donations, cleaning up trash, giving out tea and coffee during the day, and more clandestine street distributions at night, in Paris. ${ }^{56}$ Through repeat visits, we were able to spend 
considerable time socializing with refugees and volunteers, inside refugees' shelters on Chios, in nearby cafes, or on the streets in Paris. We draw heavily from these interactions in our attempt to better ethnographically capture volunteer-refugee relations, and how they are shaped by the distinct spatiotemporal conditions of the two sites.

\section{Chios Background}

A small island just a few miles off the Turkish coast, Chios has been the second main entry point for refugees fleeing to Europe across the Aegean Sea since 2015. Marked by chronic deficiencies in water, electricity, sanitation and hygiene provision, as well as health, legal aid, and protection services, conditions in the two main camps on the island - Souda and Vial - have been repeatedly denounced by human rights organizations as "inhuman and degrading." 57 The population of Souda oscillated between 600-1000 refugees between March 2016 and its closure in October 2017. Despite being jointly administered by the local municipality and UNHCR, and the presence of Greek and international NGOs such as the Norwegian Refugee Council (NRC), Praksis, Médecins du Monde, and Save the Children, Souda had many of the features of a "makeshift" camp: near the entrance, a distribution area consisting of a rudimentary roof construction and a few metal benches pitched in the gravel served as an improvised social space for refugees, volunteers, NGO and camp management staff, with a riot police bus stationed nearby. Inside the camp, lines of UNHCR field-tents, plastic containers, and large rub halls served as shelter, toilets and showers made of corrugated sheets provided only minimal sanitation, while flimsy pop-up tents spilled out onto the surrounding beach for much of the camp's existence. ${ }^{58}$ 
In this context, several international volunteer organizations and smaller collectives of local "solidarians" have been integral to the humanitarian response. The Chios Eastern Shore Response Team (CESRT), the largest team, has seen more than two thousand volunteers join since late 2015. Several tons of aid - clothes, tents, sleeping bags, and other supplies - shipped from around the world have passed through its warehouse. Salvamento Marítimo Humanitario has provided medical assistance in the camps, while the Norwegian group A Drop in the Ocean organized social activities and daily distributions of food prepared by Zaporeak, a volunteer-run kitchen from the Basque Country, in Souda.

\section{Paris Background}

In May 2016, Anne Hidalgo, the Mayor of Paris, announced the construction of a temporary refugee camp in Porte de la Chapelle - "Le Centre d'accueil pour les migrants." Informally called La Bulle (the "Bubble" in English), the camp was closed in March 2018, with more permanent accommodation systems put in place across the city. During its operation, the Bubble received much fanfare for its design: a distinctive yellow, gray, and white striped dome where refugees could hang out with a series of modular structures that accommodated 400 men who were allowed to stay for up to 10 days. Despite the acclaim the structure received as a model of humanitarian integration, it was completely fenced off, and one had to pass through a turnstile gate controlled by a security attendant; only volunteers and refugees who had already been granted accommodation inside were allowed access. The Bubble offered shelter, clothing, showers, legal aid, food, and other services and also operated as an entry point into the asylum process. However, it was unable to accommodate the hundreds of refugees arriving in Paris on a weekly basis. As a result, at times close to a thousand people slept rough in the streets nearby, in 
dire conditions, and almost completely dependent on a few local and international volunteer teams. A noticeable police presence marked the Bubble, controlling entry and restricting the ability of refugees to sleep rough through constant "evacuations." 59

The Bubble was managed by Emmaüs Solidarité, an NGO, though a clothing warehouse and distribution was supplemented by Utopia56, a grassroots organization that started operations in Dunkirk. Utopia56 volunteers have also maintained a street presence, accompanying unaccompanied children to the police station to register, escorting people to hospitals, and more generally responding to vulnerable cases. They have worked in conjunction with other small collectives such as Solidarité Migrant Wilson (SMW), Solidarithé, and Paris Refugee Ground Support, which have overlapping remits of food, tent, and clothing distribution.

There are two factors of particular importance for the analysis below that distinguish Chios from Paris. Firstly, in contrast to the heavily securitized Bubble, volunteers had almost unrestricted access to Souda throughout much of its existence. Secondly, the March 2016 EU-Turkey deal marked a radical break in the role of volunteers on Chios. The deal turned the island into a de facto prison, as thousands of refugees now had to undergo the lengthy asylum procedure on the Greek islands. ${ }^{60}$ Consequently, as detailed below, we found much thicker social relations being formed between refugees and volunteers in Chios than in the more fleeting context of Paris - a reflection of how the specific spatiotemporally of the "camp" can lend itself to different types of encounters.

\section{"Policing the line": Humanitarian Logics in Distributions}


Groups of volunteers in yellow hi-vis vests, distributing items to long queues of refugees against the backdrop of a squalid camp has become one of the iconic images associated with volunteer humanitarianism in Europe today. Camp distributions are morally ambivalent practices that, in a material and embodied sense, confront volunteers with the inevitable ethical dilemmas of humanitarian action on an everyday basis. As Harrell-Bond notes, "the contradictions inherent in 'humanitarian' assistance are most graphically illustrated in the confrontational relations between the 'helpers' and the 'beneficiaries' in the context of distributing assistance." 61 Many volunteers we spoke to viewed distributions as intensely frustrating and contentious exercises, as underscored by this pinned post on the "People to People Solidarity - Paris" Facebook page, offering advice to first-time volunteers:

Please understand that the situation is not like Calais or Dunkirk. Volunteers are being actively prevented from helping and distributing by the police... Unprepared distribution is dangerous for both volunteers and the people that you go to help. It spreads mistrust, causes anxiety, creates policing issues.

On one level, distributions run by grassroots volunteer teams do not significantly differ from those managed by established humanitarian agencies. On Chios, both volunteers and NGOs used the same distribution zone at the entrance to the camp where metal barriers were used to separate aid workers from recipients. Roles were similarly issued in both Souda and the "Bubble": some volunteers handed out items to refugees, some checked their "food cards" to determine how many items of clothing, for instance, a person is entitled to, while others supervised the distribution area to pre-empt skirmishes. Through the routine practice of "policing" distributions, 
volunteers were thus immediately placed in a relation of hierarchy vis-à-vis those they proclaim to assist. In Paris, police and guards would securitize the perimeter of the "Bubble," preventing refugees from forming lines over night. Volunteers were then routinely tasked with managing the hectic queuing system, as people were forced to make an almost mob-like descent to queue before morning entry. Even though volunteers repeatedly critiqued such heavy-handed police tactics, distributions thus inadvertently embedded volunteers in the wider regime of securitized care.

In light of recurrent tensions "in the line," longer-term volunteers in both sites felt that there was a need to self-police distributions to ensure parity across different national and ethnic communities. One team that conducted nightly clothes distributions from the back of a van in a carpark in St. Denis, where several hundred men were sleeping in tents in freezing temperatures, insisted on dividing the queue along nationality lines, each "policed" by a "leader" of their community. While practices like these arguably represent the more benign end of the spectrum of "control," they inadvertently reproduced the very divisions amongst refugee communities that volunteers sought to overcome. However, we have also seen the opposite end, where disciplinary tactics were deployed to pacify refugees, replicating the kinds of dehumanizing practices volunteers associated with the "humanitarian machine." 62 For instance, we witnessed volunteers shouting at and trying to contain crowds of frustrated refugees, berating others for "stealing" an additional second-hand jumper or taking too long to choose a pair of worn trousers. While deeply uncomfortable with the confrontational behavior of some unexperienced volunteers, Katrin, a long-term distribution coordinator on Chios, acknowledged that some form of "crowd management" is inevitable "if you want to 'control' it." Similarly, Marissa, one of the long-term 
volunteers from the Paris Sciences Po University Refugee Hub involved in daily tea, coffee, and information distribution, problematized the "line" as "inhumane" but ultimately "necessary":

Oh god. I find it awful [making refugees queue]. I totally understand why guys will get horribly frustrated with us when we're telling them 'one line' over and over again... We've tried other ways... but you very quickly become crowded and rushed. So really, the line is the only way to manage things efficiently.

Much like Feldman's Quakers in Gaza, and despite their acute awareness of the sharp inequalities they were engendering, volunteers in both sites had to routinely make compromises and put in place practices that deprived refugees of agency. The coordinator of the kitchen collective Zaporeak, for instance, recalled how "during distributions [one refugee] would sardonically bleat like a sheep...as he said we were treating them like animals." Repeat encounters of this kind threw into stark relief the difficulty, perhaps even impossibility, of enacting the principles of "solidarity humanitarianism" that many espouse. They led some volunteers to question the ethics of the relations that they enact with refugees, their own role in camp management, and their self-understanding as humanitarian actors. As Agier notes, within the humanitarian world, "criticism, and above all self-criticism, generally arise from an unease that is felt on the ground" and numerous volunteers expressed deep discomfort with traditional models of camp distribution. 63 "I got to the point," one long-term volunteer on Chios confided, "where I physically would feel ill at the idea of having to go and do distributions because I found it so degrading." Kate, a CESRT coordinator, echoed the same: 
There is a very dehumanizing aspect to handing things out... which I've grown to really hate. I can't even bear to remember... [a distribution] in Vial of T-shirts and trousers. It was probably the most ashamed I've ever felt in my life...But the other thing is we have an obligation to get this shit out of the warehouse... and make sure that people have enough to be warm.

There may be no easy way to satisfactorily navigate what Malkki calls "impossible situations" that often leave "aid workers...feeling ambivalent, inadequate, and even impure about the work that they done." ${ }^{64}$ Nonetheless, it was often during the "line," when not frantic, over cups of tea, and in the ensuing conversations, that questions not only of refugees' pasts and futures - their biographical lives - but a more dignified reimagining of care arose, even if it was unable to be always operationalized. In Kate's case, this reimagining was triggered by a concrete encounter:

This old man who was shuffling off with a crappy pair of trousers and a couple of baggy T-shirts that wouldn't fit him. He had told me about his life in Syria, he'd owned a chocolate factory and a bomb destroyed it, and killed his wife and his children and his grandchildren. And I thought: "What are you doing in this god-forsaken place?" It reminded me of that kind of dehumanizing thing that had happened to people [during the Holocaust], where they'd had rich, cultured, educated, beautiful lives that had been ruined by war. Is this the best we could do for them?

While this statement raises questions about hierarchies of deservingness embodied in volunteers' practices, it also captures their "habits of reflexivity and attention associated with the solidaristic 
ethos of equality." 65 Such processes of "explicit [ethical] deliberation" often elicited dialogue on more ethical treatment of refugees: questions of what kinds of interventions, directed to whom, and how often took up debrief meetings. ${ }^{66}$ As a result, several teams sought to create systems of aid provision that challenge, though never quite undo, its dehumanizing effects. Due to the "protracted" nature of the crisis on Chios, volunteers had more opportunities to create alternative distribution systems than in Paris. ${ }^{67}$ On Chios, some teams set up boutiques where people were offered greater privacy and time to choose items of clothing, or do tent-by-tent assessments followed by personalized deliveries rather than mass distributions covering the entire camp. Even at the very micro-level of "the line," humanitarian logics were sometimes creatively circumvented, Katrin explained:

If you have a single mother, and it's the first time she's coming for a distribution because it's difficult to line up with three kids, or leave her tent. If we know the people, it's easier to decide: "OK, whatever, you come first...or what you need I will bring it to your tent". [emphasis added]

Smaller collectives in both sites often worked with people living inside the camps in attempts not only to break down cultural and language barriers but to better respond to individual needs providing wheelchairs, sanitary pads, or culturally sensitive clothing that the more depersonalized systems operated by the UNHCR cannot deliver, or that the state neglected to deliver altogether.

Access to such aid was not always universal or fairly distributed - in large part due to its chronic scarcity—which sometimes led to charges of favoritism being levelled at volunteers. 
Nonetheless, volunteers' ability to put in place more humanizing forms of care described here, we argue, is rooted in the intimate knowledge of the camp and its inhabitants that long-term volunteers develop together with their improvisational and informal ethos. This is clearly evidenced in the daily work that many volunteers perform beyond camp distributions accompanying children, pregnant women and other vulnerable persons to hospitals, arranging translators or lawyers, and in cases of serious neglect, lobbying authorities for access to housing and other basic services on individuals' behalf.

Indeed, distributions are only one of the instances through which volunteer-refugee relations take shape. While they often mimic dominant humanitarian logics, they do not wholly determine whether creative solidarities can be formed. As discussed next, the (self-)questioning of volunteers' practices is heavily informed by encounters within and outside the camps - forms of sociality that demarcate volunteer humanitarianism from professionalized humanitarian actors.

\section{Biographical life in and beyond the camp}

The importance of the "camp" for volunteers is easy to underestimate, in terms of the social relations formed between each other and with refugees during impromptu shared meals, cups of tea, jam sessions, and "hanging" out in tents. Many volunteers saw such encounters as one of their core purposes for coming to Paris and Chios - and what drew longer-term volunteers back.

While volunteer narratives of comradery sometimes veered problematically to nostalgic remembering of a constructed utopia, any assessment of volunteers' presence in these spaces must be situated against the organized abandonment that marks refugees' existence in camps like Souda or the streets of Paris, where even the most elementary necessities for sustaining life are lacking. Against such brutalities of the camp, Rygiel reminds us, "the simple fact of feeling that 
someone cares matters." 68 "If left with only UN, people would be dying here," Jonathan, a Nigerian refugee on Chios noted. "Thank God for those volunteers. They come inside, sometimes they come to drink tea with you, they discuss with you." It is in this context that spaces emerged for an alternative humanitarianism that foregrounds biographical exchange by allowing often close, informal relations of conviviality or even friendships to develop. These forms of sociality would often carry over into spaces beyond camps - cafes, parks, street corners, and apartments. During such interactions, conversations ranged from casual banter, exchanging insights into the legal maze of the asylum regime, discovering each other's cultural customs, family backgrounds, aspirations, debating current affairs, to harrowing accounts of refugees' displacement and humiliating treatment by authorities. "Some volunteers are like brothers to me," Hayat, from Eritrea, told us. "I tell them my story and they tell me anything about them...They give us hope...They care about you like you are family."69

Spending time with refugees without an instrumental purpose not only helped bridge the common "spatial and cultural separation between aid workers and recipients of aid" in refugee camps but also transformed individual volunteers' identities and their engagement with refugees. ${ }^{70}$ Because "ethical demands thicken and increase the better you know people," Brun argues that "the durable presence of humanitarian actors...necessarily challenge[s] humanitarian principles of neutrality and impartiality."71 "Your role as a volunteer changes," Julia, who returned to Chios several times, explained:

At the beginning you come just to help people so you're a bit naïve... But when you come back and you meet people - locals, volunteers, refugees - you think about the system 
and, I have to be honest, you act also more in an emotional way: you start to know people, you get to like people so you want to help them.

Many long-term or returning volunteers like Julia developed a deep emotional attachment to people they had met in the camps and with whom they shared intimate moments of pain, anger, but also affection and joy. This resulted in various forms of emotional labor, with volunteers often finding themselves comforting individuals breaking under the psychological strain of material and legal precarity. Similarly to Doidge and Sandri's research in Calais, daily interactions generated an intense sense of "empathy" such that "inhuman conditions for refugees" came to be "seen as an attack on the individual volunteer." 72 This affective investment, in turn, fueled their humanitarian work, with teams frequently working late nights, running emergency distributions, driven by a palpable sense that "our friends" could not be left alone when the rains had flooded their makeshift homes and anger directed towards the state, UNHCR or NGOs for failing to provide basic protection.

At the same time, there are notable costs to crossing the line of "impartiality" and limits to the often close relationships formed between long-term volunteers and refugees. For some of the former, their emotional investment in the suffering of others, coupled with the lack of psychological care, eventually led to burn-outs. For the latter, friendships with volunteers would sometimes give rise to expectations - of preferential treatment or protection from deportationthat went unfulfilled. Additionally, some volunteers have maintained regular contact with their "refugee friends" via digital media once they had returned home, continuing to provide material and emotional support from abroad, and the friendships they had formed have fueled their involvement in local volunteer-run initiatives and refugee solidarity campaigns. For many others, 
however, their departure marked an abrupt end to their social ties with refugees they had encountered. ${ }^{73}$ As Fran, an English volunteer in Paris noted: "Facebook friends can become a full-on job and aren't friends in the traditional sense." She hypothetically queried: "if they [the refugees] make it to the UK would you let them crash?", illustrating how "friendships" for some could only stretch so far beyond the intensity of the camp.

Here we recall the informal and improvised nature of volunteer humanitarianis m: most volunteers we met had no prior experience in humanitarian work. Utopia56 - one of the main volunteer collectives operating in Paris - was originally an enterprise that organized music festivals. On Chios, the largest volunteer collective - CESRT — was founded by a local hotel owner and only a fraction of the hundreds of volunteers who joined the team since late 2015 had previously visited a refugee camp. Unlike established NGOs, smaller teams in particular often start with no codes of conduct, provide only a cursory induction, and individual volunteers are rarely supervised or under any formal obligation to report to camp authorities. Consequently, everyday interactions we witnessed departed sharply from the "confrontational" and "disciplinary" aid worker-refugee relations documented by Harrell-Bond and Rozakou. ${ }^{74}$ In fact, teams like Zaporeak actively encouraged their volunteers to spend time with people in the camp, sharing meals that the team had cooked, in a deliberate attempt to break down relations of inequality. Such practices are in direct violation of basic principles of professionalized humanitarianism, with NGO codes of conduct strictly forbidding personal relations with beneficiaries. At a discursive level, too, there are clear markers of distinction: while UNHCR staff would commonly refer to refugees as POCs — persons of concern — volunteers spoke of "our friends" and accused professional aid workers of treating people like "numbers." Furthermore, many insisted on calling themselves "independent volunteers" to mark out their identity from 
professionalized actors such as UNHCR or NRC. Much like in Kitching et al.'s survey of grassroots organizations on Lesvos, volunteers frequently identified against the bureaucratized and apparently inefficient official structures of securitized humanitarian care. ${ }^{75} \mathrm{At}$ times, the different modalities of humanitarianis m would collide, as vividly recalled by Julia:

I nearly had a fight with a girl from Save the Children in a meeting. She was saying we should not have any private contact with [refugees] or add them on Facebook. I didn't agree with that because I think: We're not talking about animals...It's a person. I said to her: "I agree that you feel like that because this is your job, you get paid for this...But for us, it's not our job, we choose to come here in our free time or our holiday and we have a completely different role."

It is in part through such moments of friction and "social conflict" in daily interactions with professionalized humanitarian workers that volunteers' "actions put into play conflicting interpretations" of humanitarian discourse and, by disrupting established practices and conventions of humanitarian government, that their presence serves to repoliticize the spaces in which they operate. ${ }^{76}$

Furthermore, as King reminds us, even seemingly banal activities like sharing meals, singing, playing games "are not mundane, but essential to making equality." 77 Spending time in people's shelters proved a deeply transformative experience for many volunteers for the exchange of biographies during such repeat encounters shifts the "relationship between humanitarian action and ethics" as the "ambition of saving strangers' lives turn[s] into an ambition of saving people we feel related to." 78 Such encounters thus allowed volunteers to 
move beyond the temporal confines of "emergency" humanitarian work, such as "the line," which underpins the separation between biological and biographical lives, and to recognize individuals as more than "anonymous bodies, merely human beings."79

The ability to enter into someone's makeshift shelter and form a more personal relationship was one of the distinctive social features of Souda. In addition to the materiality of a tent or UNHCR container, the accumulation of everyday household items in which one could offer a guest a cup of tea or food was simply not possible in Paris given the tenuousness of street living and the permanent threat of evacuation. In this sense, the ability to harness something - a connection, a politics, a moment—beyond the "suffering body," became more difficult, though not impossible. ${ }^{80}$ For instance, Marie, a UK-based volunteer who drives to Paris every few weeks, said that it is through brief interactions with these "men on a journey" - her deliberate phrasing that rejects the labels of "migrants" and "refugees" - that a sense of shared humanity was reinforced. They "are not just vessels to be given [provisions] to but by being able to talk to someone, there's a connection."

To be sure, enacting equality within humanitarian spaces may prove elusive as another volunteer in Chios, Mara, acknowledged: "People like to think that they're going to the camp and treating refugees as an equal. And I would say, for the most part, that's 100\% untrue." Not only do volunteers reproduce inequalities through policing practices but they can never fully escape the fundamental divide that separates them, citizens, from non-citizens denied their basic rights. Moreover, while volunteers routinely invoked the notion of "humanity" as "a category of universal solidarity" to denounce the treatment of refugees and to justify their own interventions, many gravitated towards individuals with whom they could more easily identify, in terms of culture, language, gender, or class. Thus, in Souda, the more intensive forms of socialization 
were generally confined to young, middle-class, English-speaking Syrian or Iraqi men and families, and in Paris volunteers would often gravitate towards men who shared linguistic backgrounds or were more outgoing. Like all humanitarian actors, then, volunteers face the "paradox at the heart of humanity's sentiments" - the inherent contradiction between solidarity and inequality - as they find themselves departing from its universalist claims and reproducing certain "hierarchies of lives" through their practices. ${ }^{81}$

Yet, this critique, we argue, does not fully exhaust the potentialities of refugee-volunteer encounters for disrupting humanitarian logics because it is, following Brun, the exchange of biographies that allows "social relationships of trust and mutuality rather than dependence" to develop. ${ }^{82}$ As Mara insisted, the inequalities between volunteers and refugees "can be greatly reduced by the length of time that you spend volunteering in accordance also with the friendships that are made. A big part of that comes down respect... from myself to a refugee but also the other way around. Relationships play a key role...for treating people like equals." Those exchanges were not uni-directional but, particularly in Souda, often instigated by refugees themselves, with frequent invitations for volunteers to join people inside their shelters. Repositioned temporarily as hosts, refugees were thereby "attributed the power and agency that they are typically denied in institutional aid contexts." 83

In the hybrid spatialities of Paris, volunteer-refugee encounters materialized in other ways. When authorities restricted the easy transitions between the formal "Bubble" and the "tent city," many of the makeshift practices of the camp — such as refugee-driven educational classes and social exchanges - transitioned to the latter. For a fleeting point in time prior to its demolition, the "tent city" began to reflect refugee self-expression in terms of sleeping arrangements, signs, and artwork - something which allowed volunteers to engage in an 
atmosphere more of the refugees' choosing. As Hugo, an Italian volunteer, recalled, the space enabled volunteers to see "more or less the same faces. It was almost like a village where solidarity played a role." The interactions that occurred within the "tent city" demonstrate that "as precarious as these camp spaces might be ... their residents have the spatial capability to create a rich environment with a strong sense of place." ${ }^{84}$ Furthermore, they also highlight the importance of the relationships built between volunteers and refugees in such spaces, if ready access is available.

In sum, once we zoom in on these interactions, the contours of a different modality of humanitarian action begins to emerge: an ethics of care that emphasizes "caring about rather than caring for," that brings together a concern for biological and biographical life, and that "integrates a concept of the future." 85 Youssef, a Syrian refugee who had spent eleven months on Chios, framed it thus: "volunteers come here and give us motivation, hope [that] life does not end in Greece; it's just [for] a few months, a few days, and then it can change." Ultimately, what our research shows is the possibility for refugee-volunteer encounters in which dominant humanitarian logics are at least temporarily transcended, refugee agency is retained, and exchanges of biographical life take place. Though perhaps fleeting, even the possibility of transcending such logics speaks to how we can re-envision humanitarianism, an emergent form whose value lies in the improvisation within different refugee spaces and the foregrounding of dignified care.

Crucially, as Brun suggests, once care is operationalized "as more than simply a social relation with moral and ethical dimensions" it may "also entail an alternative politics." 86 But what kind of politics is it that emerges from the practices of volunteers and their day-to-day interactions with refugees? 


\section{The Politics of Volunte ering}

As discussed earlier, one of the enduring dilemmas faced by aid workers is the "complicity of humanitarian action in processes of control and care." ${ }^{\prime 7}$ We were on several occasions privy to team meetings or ad-hoc conversations where volunteers discussed how they should separate themselves from the carceral state and biopolitical humanitarianism inside the camp, and avoid merely making the brutalities of Europe's borders a little more tolerable. ${ }^{88} \mathrm{As}$ Saz, a Paris-based volunteer reflected, a constant question prevailed in such discussions: "what are ways that we can recognize humanity in a dehumanizing situation?"

On Chios, the question of complicity became particularly acute in the aftermath of the March 2016 EU-Turkey deal. The deal transformed the temporal context in which volunteers were operating from a humanitarian emergency facing a transient population, as in Paris, to a "realm of the "protracted," with a stagnant population facing threats of deportation back to Turkey. ${ }^{89}$ Volunteers were thus no longer facilitating the crossing of borders - an inherently political act of resistance to the border regime. Instead, they were "filling the gaps" left by the humanitarian apparatus tasked with managing the refugee camps. Consequently, volunteers had to navigate a much more complex ethical and political terrain, with important implications for forging relations of solidarity with refugees. As Katrin explained: "By serving in the camp...we are becoming a part of the system...that we are actually against. It's quite hard work to make people in the camp understand the difference." In Paris too, volunteers faced dilemmas of striking a balance between providing emergency relief - where the bulk of efforts and resources are directed - and more overtly politicized interventions concerning asylum policy and housing rights for refugees. 
Across both sites, deliberations about the underlying politics of volunteering reflect the tension between neutrality and advocacy, where the former demands "a distance from politics" and the latter "calls for concerted political action on behalf of others." Yet, as Scott-Smith notes, in practice the choice is moot for humanitarian work "is inevitably a political act," particularly where the root causes of human suffering - as in the case of Europe's borders - are irreducibly political. ${ }^{90}$ This becomes evident, for example, in the refusal of most volunteers to accept state categorizations of human beings - citizens and non-citizens, "legal" and "illegal" - and their willingness to assist others in navigating (often "irregularly") Europe's borders. In this context, everyday "quiet act[s] of solidarity," such as handing out blankets to people on the streets of Paris facing routine police violence, thus become deeply political interventions that mark a clear departure from the realm of neutrality. ${ }^{91}$

The question, then, is rather "what kind of politics are involved" and what specific forms of political action do volunteers adopt in concrete settings..$^{92}$ Much like their counterparts in Calais, individual volunteers and teams have used their presence to document state abuses and make "rights-claims on behalf of refugees." ${ }^{93}$ On Chios, for example, volunteer teams have written a series of open letters to the European Commission to condemn the systemic "rights violations" resulting from the EU-Turkey deal. ${ }^{94}$ In September 2017, Utopia56 quit in protest against the inhumane treatment of refugees at the "humanitarian" Bubble, frequent deportations, and "police repression," mirroring MSF's ethic of refusal. Two months earlier, SMW - a local collective that provided breakfast on the streets since the launch of the Bubble - demanded government support for food distributions and organized a rally through their Facebook page to denounce the government's approach: 
We call for an emergency plan and call on all Parisians and commuters, all those who are ashamed to see adult exiles or children, gassed and beaten every morning, deprived of their rights, fed, clothed, cared for only by Solidarity-based citizens call on the authorities, demand political treatment of the refugee issue, which is finally human and realistic.

In framing their demands in a language of rights, targeting policy-makers and appealing to broader publics, disseminating testimonies, and in their political content - voicing opposition to key legal pillars of the EU border regime, denouncing localized bordering practices, or calling on authorities to fulfil the rights of asylum-seekers - volunteer practices bear close resemblance to long-established forms of témoignage by MSF and other NGOs. ${ }^{95}$ There are, however, a number of subtle differences that bear directly on our attempt to tease out the distinctive nature of volunteer humanitarianism. Whereas both rest their "discursive authority" chiefly on their physical presence on the ground, the legitimacy of MSF teams to speak out publicly derives from their status as respected medical "experts," whose eye-witness accounts of human suffering are buttressed by what Redfield calls a "motivated form of scientific research." 96 In contradistinction, the public figure of the volunteer is a lay witness - a concerned citizen, a friend, a fellow human being - whose witnessing derives its distinct moral force from deep personal involvement in and with the raw suffering of others.

Secondly, what distinguishes many volunteer collectives is the absence of a codified commitment to neutrality, a principle hard-wired into the institutional logics and professional norms of NGOs that tends to act as a constraint on more militant forms of political action. ${ }^{97}$ This normative flexibility grants individual volunteers and collectives a greater degree of political 
maneuver (though, as noted below, this is not always utilized). Moreover, it opens up possibilities for breaking with the dominant representational strategy in the humanitarian field whereby refugees are typically spoken for by others in the public sphere, portrayed as "mere witnesses of their own misfortune," and denied the capacity of political speech. ${ }^{98}$ To be sure, much like humanitarian NGOs, volunteers often reproduce a depolitic ized figure of the refugee in their everyday discourse. This is particularly the case with fundraising calls on social media that foreground appeals for charity and invoke the "idea of a universal, ahistorical humanity." 99 Yet, there have also been instances of volunteers engaging in collaborative acts of claimsmaking with refugees. In January 2017, a group of volunteers based on Chios collected refugee testimonies - with footage of flimsy pop-up tents and improvised shelters covered in snow recorded via smartphones - in camps across Greece to debunk the Migration Minister's claims that "there is no-one living in tents." ${ }^{100}$ By addressing their testimonies and demands directly to the Greek Minister, the campaign positioned refugees as political actors in their own right and broke with their status as mute victims. Even in Paris, the spaces of sociality allowed for interactions that affirm refugees' political agency, with refugees sharing videos captured on their cell phones of police brutality that volunteers then posted on social media.

Finally, much of humanitarian witnessing by volunteers is not labelled as such and is achieved without the professionalized publicity machines and division of labor within large NGOs. ${ }^{101}$ Grounded in an improvisational ethos, witnessing emerged as an ad-hoc, often rudimentary response to injustices observed on the ground. Nonetheless, by "weaving together...the moral and the political," such practices show that political action and humanitarian care are not antithetical, as some accounts of volunteer humanitarianism imply by demarcating “apolitical" volunteers from more "radical" activists. ${ }^{102}$ Indeed, what distinguishes volunteer 
humanitarianis $m$ from its more established modalities is precisely the willingness of many volunteers to go beyond "purely technical engagement" with suffering and practice what ScottSmith calls "inclusive solidarity" - one that is attached to "particular humans" and "involves 'taking sides."' 103 "Solidarity entails going against official actors if this means helping people keep their dignity," Eleni, a local volunteer from Chios, noted. In line with Rozakou and Sandri, we have seen many volunteers almost inadvertently become politicized: over time, they agitate, advocate, document, denounce. ${ }^{104}$ Dispensing with principles of impartiality and neutrality inevitably generates new dilemmas, contradictions, and uncertain outcomes; determining how far such practices are politically efficacious lies beyond the scope of this analysis. Rather, our more modest aim here is to give full recognition to this integral political face of volunteering.

This is not to say that volunteer humanitarianism is primarily oriented towards political action. Smaller collectives larger may lack the capacity to do so, overwhelmed by the day-to-day provision of relief. Some of the larger, more NGO-like teams have to carefully navigate the shifting political dynamics within specific sites and refrain from publicly criticizing government policies for fear of losing access to camps, their raison d'etre. CESRT, for instance, was temporarily banned from Souda after some volunteers supported a refugee-led protest during the winter of 2017. Similarly, Utopia56's departure from the Bubble jeopardized its standing with the local municipal government. In both sites, the spaces for grassroots interventions have been progressively restricted, through increased policing, ever-changing municipal "rules" on the form, frequency, and location of distributions, and continual dispersal of refugees to more carceral or distantly located sites.

It is not just conflicts with the state, however, as opposing conceptions of humanitarianis $m$ and imaginings of the future - from apolitical humanitarianis $m$ to anarchist 
confrontations to utopian ideals - often cause tensions between and within organizations. How specific teams position themselves politically vis-à-vis the state and other humanitarian actors is thus partly shaped by the conflicting political attachments of individuals. ${ }^{105}$ Some collectives began with a grassroots ethos but became larger, more hierarchical, and formalized over time, a symptom of increased donations, partnerships with major NGOs, as well as attempts by the state to regulate the informal humanitarian response. On Chios, several volunteers quit teams that were imposing "bureaucratic restrictions," as one of them put it, and "monitoring" those spending time in Souda camp. Other long-term volunteers were dismayed by a growing trend towards "voluntouris m," or what one refugee on Chios sardonically termed "holidarity." Reflecting on more than a year she spent volunteering on the island, Anna said: "It's the story of how independent volunteering and people who wanted to show solidarity were morphed into an organization that helped to keep the [refugees] here because it's in their interests."

Whether the creeping professionalization of grassroots collectives - through regulations on socializing with refugees, codes of conduct that mimic those of established NGOs, and stricter guidelines on "bearing witness" - is a necessary precondition for volunteer structures to become more durable and instrumentally effective at scale or, instead, a threat to their progressive role remains to be seen. However, the formation of new collectives and networks speaks to how some grassroots volunteers continually explore alternative ways of intervening in the "crisis" in their refusal of becoming incorporated into the structures of humanitarian government.

\section{Conclusion}

There are notable parallels between our analysis of the everyday practices and experiences of grassroots volunteers in refugee camps and the dilemmas faced by professional humanitarian 
actors over the ethics of engagement, political positionalities, and frustration at their limited capacity to affect long-term change. In this article, we have sought to intervene in the emerging debate about volunteer humanitarianism in Europe by exploring how volunteers navigate these dilemmas and, more specifically, in how far their everyday encounters with refugees produce relations that exceed humanitarian logics.

Our research suggests that such deliberative processes mark subtle but significant ruptures in how volunteers not only frame their identities and define their interactions with refugees, compared to professional NGOs like MSF or historical volunteer organizations such as AFSC, but in terms of outcomes as well. By focusing on refugee-volunteer interactions in camps that blur the lines between "formal" and "informal," we have found that the presence of volunteers plays an important role in re-humanizing and re-politicizing these spaces, thereby challenging - even if momentarily - dominant humanitarian logics. Volunteers, we have shown, may reinforce disciplinary tactics during routine work such as camp distributions, inadvertently institute new hierarchies, and sometimes offer little more than an already-moralized conception of politics. Nonetheless, everyday refugee-volunteer encounters within and beyond the "camp" contrast in important ways with the relations traditionally enacted by aid workers. The exchange of biographical life during such encounters not only allows volunteers to reimagine a more dignified provision of humanitarian care but for a different conception of the "human person" to emerge - not a passive "beneficiary," an "absolute victim," but an individual with a history, aspirations, and a distinct moral and political identity. ${ }^{106}$ In such instances, volunteer humanitarianism, however imperfectly, veers towards Malkki's "historicizing humanism that insists on acknowledging not only human suffering but also narrative authority, historical agency, and political memory" of refugees. ${ }^{107}$ What our research thus suggests is that "human 
zoology" does not necessarily exceed "biography" and the ability to build meaningful and more equal relationships through the exchange of life histories overshadows instances in which volunteers reinforce humanitarian logics of control. ${ }^{108}$

Ticktin suggests that humanitarianism takes the suffering of people on the move beyond the realm of rights into the moral (and apolitical) domain of compassion. ${ }^{109}$ Yet, in line with Givoni, our account has shown that compassion and solidarity, moral sentiment and political action are not necessarily mutually exclusive. ${ }^{110}$ Indeed, many of the volunteer practices and interactions with refugees that we have documented embody both an ethics of compassion towards suffering others as well as "political care" grounded within a politics of rights and equality. ${ }^{111}$ The elicitation of biographical life, we contend, is at the core of challenging the binaries of care and control in humanitarian reason, creating spaces for volunteers to display compassion that is not solely premised on power differential but one that recognizes the voice and agency of refugees. Exactly how such political care manifests across diverse refugee spaces, given the progressive criminalization of grassroots solidarity action and securitization of informal camps in Europe, is an important question for future research.

We do not suggest that the phenomenon of volunteer humanitarianism in Europe calls for a complete rethinking of humanitarian reason. Nonetheless, during the functioning of Souda and the Bubble, we saw not just a negative formulation of resistance - such as critiquing the "line" while recognizing its role in camp management. Instead, we saw concrete, collective strategies, and solidarity-based initiatives that resonate beyond the closure of such camps. These take on many forms, including practices of témoignage, demanding changes to specific government policies, and organizing long-term projects of integration. 
Rooted in the informal, improvisational, and egalitarian ethos of "solidarity humanitarianism," we argue that while the kind of volunteer collectives that we researched are unavoidably implicated in humanitarian government, they are never wholly subsumed by it. In fact, their presence on the ground continually exposes the systemic gaps in care left by the state and professionalized humanitarian agencies. This is arguably one reason why authorities in both locations have sought to restrict the work of volunteers: “they don't want people interfering in their [abusive] system [and] highlighting their gaps", a long-term volunteer told us on her last day on Chios. "When they are treating people as badly as they are, the last thing they want is volunteers reminding people that they have some rights." We do not suggest that volunteers display the perfect combination of compassion and politics in comparison to professional aid workers, for at times they display neither. However, as Rozakou reminds us, the task for researchers is not to "examine the ideological purity of solidarity initiatives" but to capture in how far grassroots volunteer groups responding to the "refugee crisis" throughout Europe are transforming the existing humanitarian landscape. ${ }^{112}$ While solidarity humanitarianism may be rife with contradictions and uneasy compromises, we argue that it nonetheless holds the potential for more fluid and humane responses to an ever-changing landscape of refugee flows and containment. More importantly, the volunteer-refugee encounter offers glimpses of an alternative to the violence that humanitarian reason is so often found to perform. 
${ }^{1}$ Izzy Ellis, "Refugees in Limbo on Greek Island," EU Observer, August 24, 2017, https://euobserver.com.

${ }^{2}$ Leonidas Oikonomikas, "Solidarity in Transition: The Case of Greece," in Solidarity Mobilizations in the "Refugee Crisis", ed. Donatella della Porta (Basingstoke: Palgrave Macmillan, 2018), 65-98.

${ }^{3}$ Ellis, "Refugees in Limbo on Greek Island."

${ }^{4}$ See Catherine Brun, "There Is No Future in Humanitarianism: Emergency, Temporality, and Protracted Displacement," History and Anthropology 27, no. 4 (2016): 393-410; Didier Fassin, Humanitarian Reason: A Moral History of the Present (Berkeley: University of California Press, 2012); Ilana Feldman, "The Quaker Way: Ethical Labor and Humanitarian Relief," American Ethnologist 34, no. 4. (2007), pp. 689-705; Michal Givoni, "Beyond the Humanitarian/Political Divide: Witnessing and the Making of Humanitarian Ethics," Journal of Human Rights 10, no. 1 (2011): 55-75; Peter Redfield, "Doctors, Borders, and Life in Crisis," Current Anthropology 20, no. 3 (2005): 328-361; Peter Redfield, "A Less Modest Witness: Collective Advocacy and Motivated Truth in a Medical Humanitarian Movement," American Ethnologist 33, no. 1 (2006): 3-26; Katerina Rozakou, "The Biopolitics of Hospitality in Greece: Humanitarianism and the Management of Refugees," American Ethnologist 39, no. 3 (2012); 562-577; Miriam Ticktin, "Where Ethics and Politics Meet: The Violence of Humanitarianism in France," American Ethnologist 33, no. 1 (2006): 33-49; Miriam Ticktin, "Thinking Beyond Humanitarian Borders," Social Research: An International Quarterly 83, no. 2 (2016): 255-71.

${ }^{5}$ Elisa Sandri, “'Volunteer Humanitarianism': Volunteers and Humanitarian Aid in the Jungle Refugee Camp of Calais," Journal of Ethnic and Migration Studies 44, no. 1 (2018): 65-80; Katarina Rozakou, "Solidarity \#Humanitarianism: The Blurred Boundaries of Humanitarianism in Greece," Etnofoor 29, no. 2 (2017): 99-104. See also Jane Freedman, "Amateur Humanitarianism, Social Solidarity and 'Volunteer Tourism' in the EU Refugee 'Crisis," in Humanitarian Action and Ethics, eds. Ayesha Ahmad and James Smith (London: Zed Books, 2018), 94-111; Alexandra Knott, "Guests on the Aegean: Interactions between Migrants and Volunteers at Europe's Southern Border," Mobilities 13, no. 3 (2018): 349-366.

${ }^{6}$ Redfield, "Doctors, Borders, and Life in Crisis," 330.

${ }^{7}$ Kim Rygiel, "Bordering Solidarities: Migrant Activism and the Politics of Movement and Camps at Calais", Citizenship Studies 15, no. 1 (2011): 4; Irit Katz, "Between Bare Life and Everyday Life: Spatializing Europe's Migrant Camps," Architecture_Media_Politics_Society 12, no. 2 (2017): 1-20; Simon Turner, "What is a Refugee Camp? Explorations of the Limits and Effects of the Camp," Journal of Refugee Studies 29, no. 2 (2015): 139-148.

8 Brun, "There Is No Future in Humanitarianism".

${ }^{9}$ Rozakou, "Solidarity \#Humanitarianism," 99.

${ }^{10}$ Ticktin, "Thinking Beyond Humanitarian Borders," 256; Fassin, Humanitarian Reason.

${ }^{11}$ Rozakou, "Solidarity \#Humanitarianism".

12 Fassin, Humanitarian Reason, 247; Bertrand Taithe, "Humanitarian History?" in The Routledge Companion to Humanitarian Action, eds. Roger MacGinty and Jenny Peterson, (London: Routledge, 2015), 62-73.

${ }^{13}$ Didier Fassin, "The Predicament of Humanitarianism," Qui Parle: Critical Humanities and Social Sciences 22, no. 1 (2013): 37.

${ }_{14}^{14}$ Fassin, Humanitarian Reason, 1-3.

15 Ticktin, "Where Ethics and Politics Meet," 34. 
${ }^{16}$ Didier Fassin, "Compassion and Repression: The Moral Economy of Immigration Policies in 
France," Cultural Anthropology 20, no. 3 (2005): 362-387; Barbara Harrell-Bond, "Can Humanitarian Work with Refugees Be Humane?" Human Rights Quarterly 24, no. 1 (2002): 5185.

${ }^{17}$ Liisa Malkki, "Speechless Emissaries: Refugees, Humanitarianism and Dehistoricization," Cultural Anthropology 11, no. 3 (1996): 377-404.

${ }^{18}$ Hannah Arendt, The Origins of Totalitarianism (London: Penguin, 2017), 392.

19 Turner, "What is a Refugee Camp?" 143.

20 Ticktin, "Thinking Beyond Humanitarian Borders", 265.

${ }^{21}$ Brun, "There Is No Future in Humanitarianism", 399.

${ }^{22}$ Fassin, Humanitarian Reason, 254.

${ }^{23}$ Michel Agier, "Humanity as an Identity and Its Political Effects (A Note on Camps and Humanitarian Government," Humanity 1, no. 1 (2010): 29-45; Ticktin, "Thinking Beyond Humanitarian Borders".

${ }^{24}$ Redfield, "Doctors, Borders, and Life in Crisis", 342.

${ }^{25}$ Taithe, "Humanitarian History?", 62. One of the seven Fundamental Principles of the ICRC is "voluntary service."

${ }^{26}$ Bertrand Taithe, "The Cradle of the New Humanitarian System? International Work and European Volunteer at the Cambodian Border Camps, 1979-1993," Contemporary European History, 25, no. 2 (2016): 335-358.

${ }^{27}$ Feldman, "The Quaker Way," 696-699.

28 Redfield, "A Less Modest Witness," 8.

${ }^{29}$ Givoni, "Beyond the Humanitarian/Political Divide," 56.

${ }^{30}$ Tom Scott-Smith, "Humanitarian Dilemmas in a Mobile World," Refugee Survey Quarterly 35 (2016): 1-21; Hernan del Valle, "Search and Rescue in the Mediterranean Sea: Negotiating Political Differences," Refugee Survey Quarterly 35(2016): 22-40.

${ }^{31}$ Redfield, "A Less Modest Witness," 17.

32 Redfield, "Doctors, Borders, and Life in Crisis," 343.

33 Givoni, "Beyond the Humanitarian/Political Divide," 68.

${ }^{34}$ Helena Smith, "The Idealists of Lesbos," The Guardian, April 15, 2016.

${ }^{35}$ Liisa Malkki, The Need to Help: The Domestic Arts of International Humanitarianism (Durham: Duke University Press, 2015).

${ }^{36}$ George Kitching, Hanne Haavik, Birgit Tandstad, Muhammad Zaman, and Elisabeth Darj, "Exploring the Role of Ad Hoc Grassroots Organizations Providing Humanitarian Aid on Lesvos, Greece," PLOS Currents Disasters, November 17, 2016.

${ }^{37}$ Freedman, "Amateur Humanitarianism, Social Solidarity and 'Volunteer Tourism' in the EU Refugee 'Crisis"'.

${ }^{38}$ Sandri, "Volunteer Humanitarianism," 77.

${ }^{39}$ Feldman, "The Quaker Way," 701.

${ }^{40}$ Rozakou, "Solidarity \#Humanitarianism"; Elisa Sandri and Fosco Bugoni, "Makeshift Humanitarians: Informal Humanitarian Aid Across European Close(d) Borders," in Humanitarian Action and Ethics, eds. Ayesha Ahmad and James Smith (London: Zed Books, 2018), 79-93; Freedman, "Amateur Humanitarianism, Social Solidarity and 'Volunteer Tourism' in the EU Refugee 'Crisis"'.

${ }^{41}$ Rozakou, "Solidarity \#Humanitarianism," 100.

${ }^{42}$ Katarina Rozakou, "Crafting the Volunteer: Voluntary Associations and the Reformation of Sociality," Journal of Modern Greek Studies 34, no. 1 (2016): 79-102. 
43 Oikonomakis "Solidarity in Transition," 82.

${ }^{44}$ Sandri and Bugoni, "Makeshift Humanitarians," 85, 88.

${ }^{45}$ Darragh McGee and Juliette Pelham, "Politics at Play: Locating Human Rights, Refugees and Grassroots Humanitarianism in the Calais Jungle," Leisure Studies 37, no. 1 (2018): 32; Larissa Fleischmann and Elias Steinhilper, "The Myth of Apolitical Volunteering for Refugees," Social Inclusion 5, no. 3 (2017): 17-27.

${ }^{46}$ Sandri, "Volunteer Humanitarianism," 66.

${ }^{47}$ Knott, "Guests on the Aegean".

48 Freedman, "Amateur Humanitarianism," 108.

${ }^{49}$ Ticktin, "Transnational Humanitarianism," 278.

${ }^{50}$ Turner, "What is a Refugee Camp?" 143.

${ }^{51}$ Rygiel, "Bordering Solidarities," 15; Katz, "Between Bare Life and Everyday Life". See also: Naomi Millner, "From 'Refugee' to 'Migrant' in Calais Solidarity Activism: Re-Staging Undocumented Migration for a Future Politics of Asylum," Political Geography 30, no. 6 (2011): 320-328;

${ }^{52}$ Katz, "Between Bare Life and Everyday Life".

${ }^{53}$ Michel Agier, Managing the Undesirables: Refugee Camps and Humanitarian Governance (Cambridge: Polity Press, 2011).

${ }^{54}$ Richa Nagar, Muddying the Waters: Coauthoring Feminism Across Scholarship and Activism (Urbana, Chicago and Springfield: University of Illinois Press, 2014).

${ }^{55}$ Individual or joint trips to Chios were made in March, June, November 2016, January, March, June and September 2017, and July 2018; Paris trips were made in December 2016, February 2017, June 2017, November 2017, February 2018, and March 2018. In between field visits, we also relie d on Facebook pages such as AreYouSyrious? and People to People Solidarity - Paris to keep upto-date on developments in various refugee spaces and to understand how volunteers engage with these sites. See: https:/www.facebook.com/areyousyrious/ https://www.facebook.com/groups/P2PParis/ (Accessed January 10, 2019).

56 On Chios, we volunteered with the Chios Eastern Shore Response Team. In Paris, we joined Utopia56, Solidarité Migrant Wilson, Solidarithé, and Paris Refugee Ground Support.

${ }^{57}$ Amnesty International, "A Blue Print for Despair: Human Rights Impact of the EU-Turkey Deal," (2017), See https://www.amnesty.org/en/documents/eur25/5664/2017/en/ (Accessed January 10, 2019).

${ }^{58}$ Vial serves has accommodated 1000-2,200 people since March 2016. Administered by the Greek military, access for volunteers is forbidden. Our research on Chios was thus largely confined to Souda.

59 Albert Facelly and Tanguy Garrel-Jaffrelot, "Porte de la Chapelle: The Camp Evacuated Again," Libération, August 18, 2017.

${ }^{60}$ Amnesty International, "A Blue Print for Despair".

${ }^{61}$ Harrell-Bond, "Can Humanitarian Work with Refugees Be Humane," 6.

${ }^{62}$ This does not necessarily render all "policing" immoral which stems in part from attempts to "protect" refugees from further abuse by authorities. Moreover, the desire for "control" does not simply emanate from the top-down. In spaces where gender-based violence is rife, enforcing separate queues for women and men, for instance, is often desirable.

${ }^{63}$ Agier, "Managing the Undesirables," 207.

${ }^{64}$ Liisa H. Malkki, The Need to Help: The Domestic Arts of International Humanitarianism. (London: Duke Press, 2015), 54. 
65 Millner, "From 'Refugee' to 'Migrant' in Calais Solidarity Activism," 326.

${ }^{66}$ Didier Fassin, "The Predicament of Humanitarianism".

67 Ilana Feldman, "Looking for Humanitarian Purpose: Endurance and the Value of Lives in a Palestinian Refugee Camp," Public Culture 27, no. 3 (2015): 427-447.

68 Rygiel, "Bordering Solidarities," 15.

69 The enduring mark that such relationships left on the biographies of many volunteers and refugees are captured in dozens of posts on the (closed) Facebook page "Memories of Souda camp on Chios." With more than a thousand members, its description reads: "Souda came into our life and it will remain forever. Friends, family... for ever [sic]!"

70 Taithe, "The Cradle of the New Humanitarian System?" 358.

${ }^{71}$ Brun, "There Is No Future in Humanitarianism," 404.

72 Mark Doidge and Elisa Sandri, "Friends that Last a Lifetime: The Importance of Emotions amongst Volunteers Working with Refugees in Calais," The British Journal of Sociology (2018), 11.

73 While not confined to "amateur" volunteers, as sexual misconduct "scandals" at major NGOs have revealed, there are further contentious aspects including instances of sexual relationships, even allegations of sexual exploitation: May Bulman, "Calais Jungle Volunteers Accused of 'Sexually Exploiting' Camp's Refugees." The Independent, September 22, 2016, www.independent.co.uk.

${ }^{74}$ Harrell-Bond, "Can Humanitarian Work with Refugees Be Humane"; Rozakou, "The Biopolitics of Hospitality in Greece".

75 Kitching et al., "Exploring the Role of Ad Hoc Grassroots Organizations Providing Humanitarian Aid on Lesvos, Greece".

76 Agier, "Humanity as an Identity and Its Political Effects," 40.

77 Natasha King, No Borders: The Politics of Immigration Control and Resistance (London: Zed Books, 2016), 112.

78 Brun, "There Is No Future in Humanitarianism," 405.

${ }^{79}$ Malkki, "Speechless Emissaries," 389.

80 Fassin, "Compassion and Repression".

${ }^{81}$ Ilana Feldman and Miriam Ticktin, "Government and Humanity" in In the Name of Humanity, eds. Ilana Feldman and Miriam Ticktin, (London: Duke University Press, 2010), 14-15.

82 Brun, "There Is No Future in Humanitarianism," 405.

83 Rozakou, "The Biopolitics of Hospitality in Greece," 563.

${ }^{84}$ Katz, "Between Bare Life and Everyday Life," 14.

85 Brun, "There Is No Future in Humanitarianism," 393.

86 Brun, "There Is No Future in Humanitarianism," 405-406.

${ }^{87}$ Polly Pallister-Wilkins, "Hotspots and the Politics of Humanitarian Control and Care," Society \& Space, December (2016).

${ }^{88}$ Freedman, "Amateur Humanitarianism in the EU Refugee "Crisis"".

${ }^{89}$ Feldman, "Looking for Humanitarian Purpose," 429.

90 Scott-Smith, "Humanitarian Dilemmas in a Mobile World," 8-9.

91 Ibid., 15.

92 Ibid., 9.

93 McGee \& Pelham, "Politics at Play," 11.

94 See: http://www.statewatch.org/news/2018/feb/greece-chiou-com-complaints.htm (Accessed January 10, 2019). One of the authors of this paper was involved in the drafting of these letters. 
95 MSF has repeatedly denounced conditions in Greece and Paris: "Critical Situation for Refugees and Migrants Stuck on Paris Streets as Winter Approaches," November 16, 2017; "Moria Is in a State of Emergency," September 17, 2018, https://www.msf.org/ .

96 Redfield, "A Less Modest Witness," 3, 13.

97 Scott-Smith, "Humanitarian Dilemmas in a Mobile World".

98 Johanna Siméant, "Interpreting the Rise of International 'Advocacy,"” Humanity 5 no. 3 (2014): 323-343.

99 Malkki, "Speechless Emissaries," 379.

100 Entitled "I Live in a Tent," the YouTube video circulated widely on refugee solidarity Facebook platforms, reaching tens of thousands of viewers: https:/tinyurl.com/y $90 \mathrm{oq} 67 \mathrm{v} 4$ (Accessed January 10, 2019).

101 Siméant, "Interpreting the Rise of International "Advocacy",.

102 Givoni, "Beyond the Humanitarian/Political Divide," 68-70. In her study of No Borders movements in Calais and Athens, King refers to "humanitarians" as "collaborators with the state, depolitic is ing the situation ... allies in the struggle for the freedom of movement up to a certain point [but] also one of the biggest obstacles to it" (King, "No Borders," 124).

103 Scott-Smith, "Humanitarian Dilemmas in a Mobile World," 16.

104 Rozakou, "Solidarity \#Humanitarianism"; Sandri, "Volunteer Humanitarianism".

105 Shortly after the EU-Turkey deal came into effect, a heated debate ensued at CESRT's daily meeting over whether the team should provide milk to infants in Vial. While some insisted on the team's moral duty to offer assistance wherever a need arose, the majority of volunteers refused to provide aid in a military-run camp where refugees' fundamental rights were being violated. By the summer of 2018, CESRT had become the main supplier of non-food items to Vial, illustrative of how the politics of collectives can shift over time.

106 Agier, "Humanity as an Identity and Its Political Effects," 37.

107 Malkki, "Speechless Emissaries," 398.

108 Redfield, "Doctors, Borders, and Life in Crisis," 342.

109 Ticktin, "Thinking Beyond Humanitarian Borders".

110 Givoni, "Beyond the Humanitarian/Political Divide".

111 Ticktin, "Thinking Beyond Humanitarian Borders," 256.

112 Rozakou, "Solidarity \#Humanitarianism," 104. 